\title{
Political Cartoon Discourse: Creativity, Critique and Persuasion
}

\author{
El Discurso de las Viñetas Políticas: Creatividad, Crítica y Persuasión
}

JUANA I. MARÍN-ARRESE

UNIVERSIDAD COMPLUTENSE DE MADRID

ABSTRACT: This paper aims to explore the potential of political cartoon discourse for creativity, critique and persuasion, in the representation of social actors and events and in the evaluation of the consequences of Brexit. The paper focuses on the use and interaction of metaphors, metonymies, blending strategies, and cultural models in cartoons depicting the Brexit conundrum, from the perspective of Critical Metaphor Analysis (CMA) (Charteris-Black, 2011; Musolff, 2012) and Multimodal Critical Discourse Analysis (MCDS) (Machin, 2013). The case study adopts an integrated multifaceted framework in the analysis of a representative sample of cartoons selected from quality newspapers published in the UK. The aim is to reveal the synergistic interplay in: (a) the use of metaphors, metonymies, blending strategies, and cultural models in the depiction of social actors, phenomena and events; (b) the features of creativity in the expression of political commentary by professional cartoonists (novelty, recontextualization); and (c) the role of political cartoons in the critique and challenge of political power, by creating counter-narratives and acting as vehicles of persuasion.

Key words: metaphor, multimodality, critical discourse studies, political cartoon discourse, creativity, persuasion

RESUMEN: Este artículo pretende explorar el potencial del discurso de viñetas políticas para la creatividad, la crítica y la persuasión, en la representación de los actores sociales y los eventos, y en la evaluación de las consecuencias del Brexit. El trabajo se centra en el uso e interacción de metáforas, metonimias, estrategias de fusión conceptual, y modelos culturales en viñetas que representan el dilema del Brexit, desde la perspectiva del Análisis Crítico de la Metáfora (ACM) (Charteris-Black, 2011; Musolff, 2012), y Análisis Crítico del Discurso Multimodal (ACDM) (Machin, 2013). El estudio de caso adopta un marco integrado multifacético en el análisis de una muestra representativa de viñetas, seleccionadas de periódicos de calidad publicados en el Reino Unido. El objetivo es desvelar la interacción sinérgica entre: (a) el uso de metáforas, metonimias, estrategias de fusión conceptual, y modelos culturales en la representación de actores sociales, fenómenos, y eventos; (b) los rasgos de creatividad en la expresión del comentario político por parte de humoristas gráficos profesionales 
(innovación, recontextualización); y (c) el papel del humor gráfico político en la crítica y el desafío del poder político, mediante la creación de contra-narrativas y como vehículos de persuasión.

Palabras clave: metáfora, multimodalidad, análisis crítico del discurso, humor gráfico político, creatividad, persuasión

\section{INTRODUCTION}

Political cartoons configure the discursive construction and qualification (positively or negatively) of social actors, phenomena or events (Wodak \& Meyer, 2015), and play a crucial role in challenging claims made by politicians and the face-saving strategies they engage in, and in highlighting the inconsistencies of political decisions and practices (Marín-Arrese, 2005, 2015, in press). Two dimensions of meaning construction are central in political cartooning: the humorous pictorial depiction and the political butt or critical stance expressed in the cartoon. Political cartoons may both reflect and reinforce or reshape public opinion and readers' beliefs or points of view on specific socio-political issues as well as their social and cultural attitudes (Schilperoord \& Maes, 2009).

The paper aims to explore the potential of political cartoon discourse for creativity, critique and persuasion, in the representation of social actors and events and in the evaluation of the consequences of Brexit.

RQ1: The first set of research questions centre on the issue of representation and depiction strategies: How are the main social actors (key UK politicians) depicted in the cartoons? How is Brexit conceptualized and depicted? How do metaphor and other cognitive mechanisms interact with cultural models to yield various metaphor-blend-model combinations in the representations of social actors and events in the cartoons? Do we find common metaphors, blending strategies, or cultural models in the cartoons and in the language of politics and the press?

The paper examines recurrent themes in the conceptualization and cartoon depiction of social actors and recent events in the UK and the EU concerning the Brexit conundrum, which have received special attention in the press, such as the Brexit Referendum (2016) and the issues derived thereof. As we will see, these depictions reveal common and consistently shared conceptualizations in the representation of social actors and events in the political cartoons, and in the discourse of politicians and the media (Chilton \& Ilyin, 1993; Bergen, 2004; Charteris-Black, 2011; Musolff, 2012; MarínArrese, in press).

The paper also seeks to examine the ways in which cartoons are used to evaluate the potential consequences of Brexit, and provide a site of critique, dissent and transgression (Marín-Arrese, 2005, 2015).

RQ2: The second set of research questions focus on the strategies for the de-construction of pro-Brexit scenarios: What plausible counter-scenarios are depicted in the cartoons? What types of narrative genres are evoked as framing and re-framing devices in the cartoons? What is the role of intertextuality in the construction of counter-scenarios?

The paper focuses on the strategies of de-construction of pro-Brexit scenarios in cartoons by providing figurative counter-scenarios as plausible frames for evaluating the consequences of Brexit (Musolff, 2017). As we will see, in the counter-scenarios created by the cartoon there is an interplay of familiar and recurrent cultural representations (symbolic images, allegorical representations, personification, person-animal hybrids, 
monsters and supernatural adversaries, etc.), with familiar narrative genres as framing and re-framing devices (mythology, legends, fairy tales, films, songs, etc.), as well as intertextuality in the use of allusions, parody, and quoting and re-quoting from historical and literary sources (Kövecses, 2010; Semino et al., 2013; Gibbs, 2015; Reijnierse et al., 2015; Musolff, 2017; Marín-Arrese, in press). As such, this paper provides further evidence on the use of political cartoons as the ideal site for creativity, as both novelty and recontextualization (Bergen, 2004; Marín-Arrese, 2008; Hidalgo et al., 2013; MarínArrese, in press).

The case study thus adopts an integrated multifaceted framework in the analysis of a representative sample of cartoons selected from quality newspapers with a clear proremain stance, The Guardian and The Observer. For the analysis, the paper draws on the work on metaphor, metonymy, blending, and cultural models in theoretical and analytical frameworks such as Conceptual metaphor theory (CMT) (Lakoff \& Johnson, 1999), Blending (Fauconnier \& Turner, 2002), Cultural models (Holland and Quinn, 1987). The paper adopts the general perspective of Critical Discourse Studies (Wodak \& Meyer, 2015 ), in the focus on representation of social actors and events, and more specifically that of Critical Metaphor Analysis (CMA) (Charteris-Black, 2011; Musolff, 2012) and Multimodal Critical Discourse Analysis (MCDS) (Machin, 2013). Comparison mechanisms such as metaphoric reasoning and conceptual integration or blending in visual and multimodal metaphors provide the schematic depiction of source and target domains and scenarios in juxtaposition. Work on Humour studies and cartoon discourse is particularly relevant to unveil the crucial part played by incongruity and salience imbalance of scenarios in cartoons (Coulson, 2002; Fauconnier \& Turner, 2002; Brône \& Feyaerts, 200; Giora, 2003; Bergen, 2004; Forceville, 2009; Marín-Arrese, 2015).

The aim is to reveal: (a) the synergistic interplay in the use of metaphors, metonymies, blending strategies, and cultural models in the depiction of social actors and events in the cartoons, and how they parallel the language of the media and politics; (b) the features of creativity in the expression of political commentary by professional cartoonists (novelty, recontextualization); and (c) the role of political cartoons in the critique and challenge of political decisions and power, by creating counter-narratives and acting as vehicles of persuasion.

The paper is divided into five sections. Section 2 briefly describes the notions of creativity, critique and persuasion as they apply in cartoon discourse, and the theoretical framework. Section 3 provides contextual information regarding the Brexit conundrum. The case study and the methodology are described in Section 4. Section 5 presents the results of the analysis and the discussion and interpretation of the political cartoons selected on the topic of Brexit. The conclusions are given in the final section.

\section{CREATIVITY, CRITIQUE AND PERSUASION}

Political cartoons provide the ideal site for 'creativity' as innovation and recontextualization, involving the interaction of cognitive mechanisms, such as metaphor and blending, and semiotic resources (Marín-Arrese, in press). Sternberg and Lubart (1999: 3) provide a definition of creativity as "the ability to produce work that is both novel (i.e. original, unexpected) and appropriate (i.e. adaptive concerning task constraint)". As regards the definition and constraints on creativity, Kaufman and Sternberg (2010: 468) argue that "creativity has a property that is not true of all psychological constructs -it exists in the interaction of the stimulus and the beholder. [...]. Moreover, what is creative to one audience may be seditious or even treasonous to another". Langlotz (2015: 40-41) defines creativity in terms of the cognitive capacities 
"that make it possible for human beings to shape new, original, unprecedented, or unconventional products that depart from familiar, established, predefined, and fully predictable outcomes".

Political cartoons may be viewed as "an independent source of evidence on the creative use of cognitive mechanisms", such as metaphor, blending and cultural models (Bergen, 2004: 24). Within humour studies, there is a growing field of study of metaphor and blending in cartoons (Fauconnier and Turner, 2002; Coulson, 2002; Bergen, 2004; Marín-Arrese, 2005, 2008), and of metonymy as an 'unpacking device' (Brône and Feyaerts, 2003). As Bergen (2004: 24) observes, "since political cartoons use these functions in a different modality from the conventional linguistic one, the discovery of the use of common metaphors, blending strategies, and cultural models in language and in editorial cartoons can serve to confirm the non-linguistic nature of these cognitive mechanisms". What is more, the capacity of metaphor for recruiting conceptual materials from highly variable contexts provides an inherent potential for novelty as creativity (cf. Kövecses, 2010). Metaphor likewise exhibits a unique capacity for adaptability of familiar concepts or experiences to new contexts, and for their recontextualization to yield unexpected meanings and interpretations (Kövecses, 2010; Semino et al., 2013; Hidalgo et al., 2013).

Cognitive mechanisms such as metaphor in cartoons may be verbal, visual or multimodal, where each of the modes may evoke, either independently (monomodal metaphor) or in combination (multimodal metaphor), both source and target domains of the metaphor. In visual and multimodal metaphors, there is a juxtaposition of source and target domains, and access to the target domain scenario and the representation of target domain entities or events is triggered by some linguistic or visual interpretative cue (Bergen, 2004; Forceville, 2009). Blending is particularly relevant in cartoons, where we visually access a blended mental space where some form of incongruity or cognitive clash between two world representations is patent. The interpreter undergoes the cognitive shift from an initial salient scenario to an alternative non-salient or less salient and novel scenario (Marín-Arrese, 2005, 2008, 2015). In the words of Fauconnier and Turner (2002: 333), "at first we recognize a space with incongruities" and "those incongruities prompt us to take the space as a blend and look for its inputs". It is the existence of this incongruity or cognitive clash which triggers the unpacking of the blend, by projecting backward to the input spaces. This creative process yields unexpected inferential and emotional effects which contribute to the humour appreciation (Coulson, 2002).

Political cartoon discourse is an invaluable instrument of 'critique', strategically using humour as transgression in order to challenge political power and to provide contest for symbolic power. Cartoons provide a site for struggle in the contest for the terrain of symbolic power in that they may be used to legitimise, or resist, attitudes and beliefs which may be prevalent at a particular moment in society and in public discourse (Bourdieu, 1991; Van Dijk, 1998; Marín-Arrese, 2005; Gibbs, 2015; Thurlow \& Jaworski, 2017). Political cartoons combine caricature, satire and humour to convey socio-political commentary, the critical butt aimed at powerholders, which calls into question the legitimacy of certain social norms and specific policies or practices (MarínArrese, 2005, 2015). As Koestler (1989: 73) observes, in the comic effect of satire or the projection by means of allegory,

[...] we are made suddenly conscious of conventions and prejudices which we have unquestionably accepted, which were tacitly implied in the codes in control of our thinking and behaviour. The confrontation with an alien matrix reveals in a sharp, pitiless light what we failed to see in following our dim routines; the tacit assumptions hidden in 
the rules of the game are dragged into the open. The bisociative shock shatters the frame of complacent habits of thinking; the seemingly obvious is made to yield its secret.

The potential of humour as an instrument of dissent and transgression has been repeatedly pointed out in the literature. Speier (1998: 1395) argues that "throughout history, whispered jokes have been safety valves, enabling men to reduce the frustrations inflicted through taboos, laws, and conventions". Douglas (1968: 369) very perceptively describes joke-telling as a form of 'anti-rite', in that a rite connects widely differing concepts which support each other: "The rite imposes order and harmony" by creating "unity in experience" and asserting "hierarchy and order". Jokes, however, have the opposite effect: "They connect widely differing fields, but the connexion destroys hierarchy and order. They do not affirm the dominant values, but denigrate and devalue. Essentially a joke is an anti-rite". Cartoons similarly contribute to effectively erode the logic of the established order, and the perception of order and harmony (cf. Marín-Arrese, 2005).

The 'persuasive' power of cartoons as carriers of narratives lies in their capacity for the de-construction of familiar scenarios and the construction of figurative counterscenarios as plausible frames, which works as an effective means of shaping beliefs and public opinion (Musolff, 2017; Marín-Arrese, in press). Metaphorical scenarios and figurative framing provide the means "to build narrative frames for the conceptualization and assessment of political issues and to 'spin out' these narratives into emergent discourse traditions" (Musolff, 2006: 36). Cartoons provide apt counter-narratives, by drawing on cultural schemata, allusion and other features of intertextuality and thus revisiting narratives and creating narrative reconstructions of reality (Marín-Arrese, in press).

The paper will focus on the de-construction of pro-Brexit scenarios and the ways in which cartoonists make use of the joint deployment of cognitive mechanisms, cultural schemata, intertextuality, and features of humour, to construct figurative counterscenarios as plausible frames for evaluating the consequences of Brexit. Through the analysis of cartoon discourse, the paper will unveil the use of metaphors, metonymies and blending deployed in common multimodal referential and predicational strategies in the discursive construction and evaluation of the main social actors, entities and events in the process of Brexit.

The paper will also make visible the evaluation of the consequences of Brexit, the critique and challenge of UK politicians in power, and the context of their exercise of symbolic power with respect to Brexit through the use of recurrent cultural representations (symbolic images, allegorical representations, person-animal hybrids, wild animals, monsters and supernatural adversaries, etc.), and the recontextualization of familiar narrative genres (mythology, legends, folklore tales, fairy tales, films, etc.), as counter-narratives and vehicles of persuasion (Musolff, 2006, 2017; Marín-Arrese, in press).

\section{THE BREXIT CONUNDRUM}

The Accession of the UK to the European Communities (EC) took effect on 1 January 1973, and its membership was confirmed by a referendum held in June 1975, the United Kingdom European Communities membership referendum. Quite early on, and particularly from the 1990s, there was a notable increase in Euroscepticism; surveys showed an increase from $38 \%$ in 1993 to $65 \%$ in $2015^{1}$. Among politicians, there were

\footnotetext{
${ }^{1}$ Cf. https://populartimelines.com/timeline/Brexit
} 
increasing numbers of advocates of withdrawal, notably the Eurosceptic Conservative Party members and the UK Independence Party (UKIP), formed in 1993, and a gradual rise in anti-EU feelings in the UK. As Musolff (2017: 641) points out, the development of one of the key metaphors conceptualizing the relationship between the UK and the EU, present in the slogan, Britain at the heart of Europe, "shows a decline in its affirmative, optimistic use, and a converse increase of deriding uses to the point of declaring the heart of Europe irredeemably diseased, dead, non-existent or rotten".

In the 2015 General Election, Prime Minister David Cameron pledged to hold a referendum, which was included in the 2015 Conservative Party manifesto. As a result, the United Kingdom European Union membership referendum was held on 23 June 2016, and the results yielded a majority vote of $52 \%$ in favour of leaving the EU. Following David Cameron's resignation, Theresa May was chosen as the new Leader of the CP, and Prime Minister on 13 July 2016, and the Department for Exiting the European Union was created in July of that year. In March 2017, the House of Commons passed the European Union (Notification of Withdrawal) Act 2017 (c. 9), which conferred on the PM the power to invoke Article 50 of the Treaty on European Union. The letter invoking Article 50 and the start of the withdrawal process of the UK from the EU was delivered to European Council President Donald Tusk on 29 March 2017, which effectively initiated the twoyear period for Brexit negotiations and set the date of withdrawal for the 29 March 2019.

In July 2018, Theresa May's Government presented a White Paper to Parliament, The future relationship between the United Kingdom and the European Union, also known as the Chequers plan or agreement, since it had been drawn up at Chequers, the PM's residence in the country. The plan was rejected by the EU in September 2018, and a final compromise was reached with the EU in the Draft Agreement on the withdrawal of the United Kingdom of Great Britain and Northern Ireland from the European Union and the European Atomic Energy Community, which was published on 14 November 2018, and endorsed by EU27 on 25 November 2018. However, the House of Commons repeatedly voted against the agreement, so that Theresa May was forced to ask the EU for an extension of the period allowed for the Brexit negotiation, which was finally granted for 31 October 2019. Following repeated failures to reach a compromise in Parliament, Theresa May presented her resignation as Leader of the Party, on 24 May and effectively as PM on June $12^{\text {th }} 2019$.

At the heart of the debates in Parliament are some key issues involving the choice between so-called 'Hard' vs. 'Soft' Brexit: whether the UK establishes trading with the EU on the basis of World Trade Organisation (WTO) rules, but with no obligation to accept free movement of people, or whether the UK remains in the EU single market for goods and services, which means that they would have to comply with Economic European Area (EEA) rules regarding the free movement of people. Another key issue is the Northern Ireland Protocol, or Irish Backstop, which would prevent a hard border in Ireland between the Republic of Ireland and the UK, but which would keep Northern Ireland within the European Union Customs Union and the European Single Market, which naturally is strongly opposed by the Democratic Unionist Party (DUP).

Severe warnings have been issued regarding the consequences of Brexit. The Oxford Review of Economic Policy published a Supplement, v. 33 (2017) with a number of studies on the consequences of Brexit, among them the economic impact of Brexit, labour immigration and higher education, among others. Economic studies on the effects of Brexit point to a considerable reduction of the Bank of England's projections of Gross Domestic Product (GDP), the fall in the value of sterling, and reductions in UK's real per capita income in the medium term and long term (cf. Johnson \& Mitchell, 2017). Freedom of movement in the higher education sector may affect "loss of research funding from EU 
sources; loss of students from other EU countries; the impact on the ability of the sector to hire academic staff from EU countries; and the impact on the ability of UK students to study abroad" (Mayhew, 2017: S155). During the Leave campaign, many of these issues were dismissed as Anti-Brexit scaremongering.

\section{CASE STUDY: METHODOLOGY}

\subsection{RESEARCH OBJECTIVES}

This paper explores the potential of political cartoon discourse for creativity, critique and persuasion, in the representation of social actors and events and in the evaluation of the consequences of Brexit. The research objectives are the following:

(i) Creativity: to identify features of innovation and recontextualisation in the use of metaphor, metonymy and blending strategies in the depiction of social actors and events, based on the use of allegory, myth and symbol and in the use of familiar narrative genres (mythology, legends, folklore tales, fairy tales, films, etc.).

(ii) Critique: to identify features of humour, allusion and parody, in the expression of dissent and transgression, and their role in challenging political power and in contesting the exercise of symbolic power.

(iii) Persuasion: to identify features of intertextuality in the use of narrative genres and the de-construction of familiar scenarios and construction of figurative counterscenarios, or counter-narratives, as plausible frames and vehicles of persuasion.

\subsection{Data SOURCES}

The cartoons were selected from the webpages of professional cartoonists in the quality newspaper, The Guardian and its sister newspaper The Observer. Since these newspapers have taken an unequivocal anti-Brexit position, they were thought to be an appropriate source of data for a critical evaluation of the social actors and events involved in the process of Brexit. The following are the regular cartoonists in The Guardian and The Observer, the number of cartoons collected on the topic of Brexit during the period mentioned, and their webpages:

(a) Steve Bell: 186 https://www.theguardian.com/profile/stevebell

(b) Ben Jennings: 45 https://www.theguardian.com/profile/ben-jennings

(c) Chris Riddell: 73 https://www.theguardian.com/profile/chrisriddell

(d) Martin Rowson: 113 https://www.theguardian.com/profile/martinrowson

The cartoons were collected from February 2016 to November 2018, that is, from close and prior to the Referendum date of 23 June 2016, and through the Post-Referendum negotiations until the end of the negotiations with the EU of the draft Withdrawal Agreement (November 2018). Among the most representative cartoons are those selected for analysis here, since they focused on key events in the process of Brexit, alluded to above in Section 3:

- Economic studies on the effects of Brexit. 
- Scepticism of pro-Brexiters regarding severe warnings regarding the consequences of Brexit.

- Debates in Parliament involving the choice between so-called 'Hard' vs. 'Soft' Brexit.

- The Chequers plan, the White Paper to Parliament on The future relationship between the United Kingdom and the European Union.

- The Northern Ireland Protocol, or Irish Backstop.

The main social actors involved in the process and most recurrent in the representations in the cartoons are the following:

- Theresa May, Leader of the Conservative party, served as UK Prime Minister from 2016 to 2019.

- Boris Johnson, Secretary of State for Foreign and Commonwealth Affairs, 2016-2018.

- George Osborne, Chancellor of the Exchequer under Prime Minister David Cameron from 2010 to 2016.

- Michael Gove, Secretary of State for Justice from 2015 to 2016, Secretary of State for Environment, Food and Rural Affairs in the cabinet reshuffle on 11 June 2017.

- Jeremy Corbyn, Leader of the Labour Party and Leader of the Opposition since 2015.

- Tony Blair, Leader of the Labour Party, served as UK Prime Minister from 1997 to 2007.

- Nigel Farage, MEP, UK Independence Party (UKIP)

- Arlene Foster, Leader of the Democratic Unionist Party (DUP).

\subsection{STAGES IN THE INTERPRETATION PROCESS OF CARTOONS}

Political or editorial cartoons are a multimodal mode of communication, where meaning is typically constructed via two semiotic modes, the verbal and the visual. They generally consist of single-panel, or multiple-panel, cartoons with captions and sometimes speech balloons, which are usually placed on the editorial page of newspapers and news websites to co-construct and express editorial opinion. In addition to the content or depicted scenario and the verbal elements (captions, labels, etc.), it is essential to consider the local contextual aspects of the cartoon, all of which affect meaning construction and contribute to unravel the point of the cartoon.

In the process of interpretation and deconstruction of cartoon discourse ${ }^{2}$, we may identify a number of processes and stages, not necessarily sequential (Marín-Arrese, 2005, 2008, 2015, in press).

(i) Set-up phase: The cartoon genre, as other forms of humour, requires the 'willing suspension of disbelief' (Coleridge, 1817), and the initial building of expectations which are 'congruous' and compatible with some discourse world.

(ii) Contextual, cultural and socio-political knowledge: The deconstruction process necessarily draws on sources of knowledge as a guide to the recognition and interpretation of figurative scenarios and entities.

\footnotetext{
2 This process of interpretation and deconstruction of cartoons will be carried out in full for the first of the Brexit cartoons selected; because of space limitations only the most relevant processes and stages will be discussed for the rest of the cartoons.
} 
(iii) Simultaneous visual access: In accessing the cartoon there is an initial simultaneous perception of the visual representation of at least two scenarios and all the elements of the cartoon (caption, speech balloons, etc.), and of the incongruity and the appropriate cues which function as stimuli in the interpretation process.

(iv) Salient scenario: Recognition of a salient familiar scenario (Giora, 2003), Scenario 1, and construction of the most relevant interpretation of the visual representation on the basis of the entities and situations depicted, and the expectations which are congruous and compatible with this scenario. Salience (familiarity, frequency, conventionality, and prototypicality) and "novelty that allows for the recoverability of the familiar" are two of the key elements involved in innovative forms of discourse (Giora, 2003: 176).

(v) Incongruity phase: An incongruity is detected within this initial salient scenario, where the interpreter becomes aware of some clash or divergence from expectations, involving some discrepancy or incoherence regarding expected elements of the scenario, rational behaviour, etc., which triggers the search for a cue to an alternative interpretation.

(vi) Cue: A relevant cue, visual or verbal, prompts metonymic access to an alternative, non-salient, novel meaning or scenario. In multimodal cartoons, the interpretative cue is characteristically found in the verbal element, or else in the interaction between a verbal prompt and some visual interpretative cue (Brône and Feyaerts, 2003).

(vii) Reinterpretation or 'Revisitation': The incongruity and the cue trigger the alternative interpretation process, which enforces a reversal or shift whereby the salience imbalance is reassessed, and the process of unpacking the blend generates a non-salient novel interpretation or scenario, Scenario 2, is now considered (Fauconnier \& Turner, 2002; Giora, 2003).

(viii) Resolution phase: The resolution phase, where the salient meaning is discarded, though not necessarily suppressed or cancelled in the case of cartoons, and the non-salient interpretative scenario is adopted.

(ix) Critique: Cartoons create a highly complex message, which serves to reinforce or challenge social, cultural, and political practices.

(x) Emotion arousal: Derived from the representations and the critique, and also in part through the sense of complicity and shared intentions with the cartoon producer.

(xi) Intentionality and Persuasion: An essential ingredient in the humour process is the intentionality or the 'raison d'être' of the cartoon, the intended persuasive effect.

\section{INTERPRETATION AND DISCUSSION}

\subsection{REPRESENTATION OF SOCIAL ACTORS AND STANCE OF POLITICAL PARTIES}

In this section we will provide a more in-depth analysis of two related cartoons which focus on the political stance of the Labour party and the main social actors involved, one published prior to the Referendum (23 June 2016), and another one after the Referendum.

The contextualization for the first cartoon is found in the speech by Jeremy Corbyn, Labour Leader, where he stresses that "a Conservative government would take the opportunity of Brexit to slash protection for workers, in a "bonfire of rights" ("Leaving EU would lead to 'bonfire of rights"', The Guardian, 14 April 2016). 
(1) PRE REFERENDUM: Jeremy Corbyn's EU stance: "Labour leader calls for vote against Brexit, warning of a 'bonfire of rights' if Britain leaves the European Union" (Bell, The Guardian, 14 Apr 2016).

https://www.theguardian.com/commentisfree/picture/2016/apr/14/stevebell-jeremy-corbyn-eu-cartoon

The cartoon by Bell depicts a war/revolution scenario, with Jeremy Corbyn raising the European flag in his right hand and carrying a musket in his left hand. At his side are several MPs, and three figures are kneeling or lying at his feet, the caricatured representations of Cameron, Osborne and Blair. In the background, there are combatants carrying weapons, and the Houses of Parliament. There is multimodal cueing in the cartoon which jointly provide access to the salient scenario of the July Revolution of 1830, input space 1 of the blend. The caption with the words "After Delacroix", provides access to the painting by Delacroix, Liberty Leading the People, commemorating the July Revolution of 1830, which toppled King Charles X of France. The visual cue is found in the visual representation and perceptual resemblance to the scene depicted in Delacroix's painting, where La Marianne, the personification of the Goddess of Liberty, leads the people forward over a barricade and the bodies of the fallen, holding the flag of the French Revolution -the tricolour- in one hand and brandishing a bayoneted musket with the other. La Marianne, the national symbol of the French Republic, is an allegory of liberty and reason, and evokes the revolutionary ideals vindicated by the French Revolution: 'Liberty, Equality and Fraternity'.

A patent incongruity in the cartoon blend is the caricature of Jeremy Corbyn, in the role of La Marianne, instantiating the metaphor CORBYN IS LA MARIANNE, leading the fight for Europe, for 'Remain', cued by the European flag, symbol of Europe. Unexpected deviations are also found in the depiction of other politicians: Tony Blair, with a masklike face, bulging eyes and pointed ears, resembling a Dark Lord of the Sith (Star wars), George Osborne, "in a gimp mask and bondage gear"3, and Cameron as 'rubber man', all victims of the political carnage. In the revisitation and de-blending process, we access an alternative scenario, input space 2, the Parliamentary debates on Brexit, where the Labour party is concerned about effects for the working class, and Cameron and the Conservatives are unable to provide leadership.

\footnotetext{
${ }^{3}$ Tim Benson: Holding politicians to account: The cartoonists perspective. http://www.original-politicalcartoon.com/cartoon-history/holding-politicians-to-account-the-cartoonists-perspective/
} 


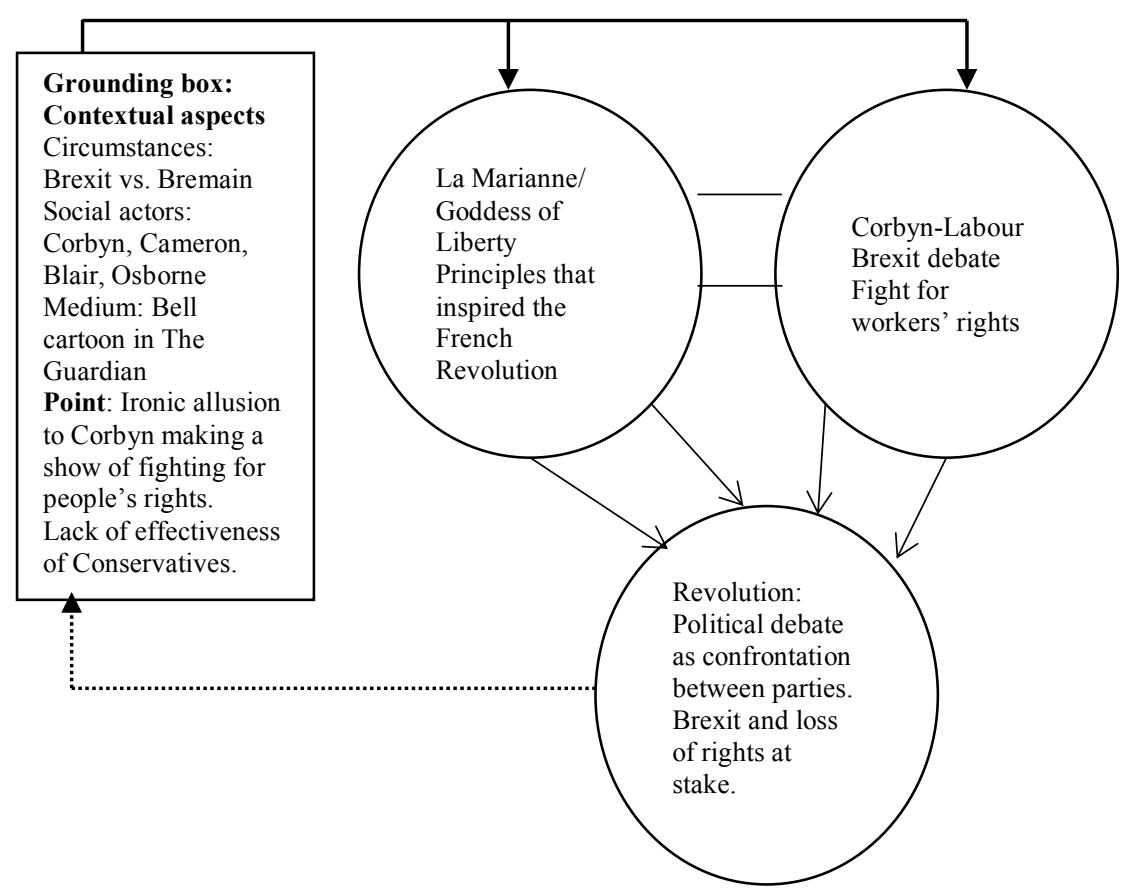

The critique and interpretation of the cartoon points to an ironic representation of Jeremy Corbyn as La Marianne/The Goddess of Liberty, in allusion to his statement that leaving the EU would lead to a 'bonfire of rights' (The Guardian, 14 April 2016), in which Corbyn is making a show of fighting for people's rights. The cartoonist presents Brexit as the destruction of liberty/rights, and suggests that there is a need for the Labour party to lead the pro-EU revolution. The Conservative party (Cameron) is represented as lacking initiative and totally ineffective in the Bremain campaign. There are also political victims and potential treachery and betrayal in both Labour (Blair) and Conservative (Osborne) camps.

The context for the post-Referendum cartoon by Rowson is found in Tony Blair's speech at the Open Britain event, where the former PM "accused a 'debilitated' Labour party of allowing a disastrous Brexit to happen, as he called for a cross-party political movement to oppose leaving the EU" ("Tony Blair: debilitated Labour is facilitating a disastrous Brexit", The Guardian, 17 February 2017).

(2) POST REFERENDUM: Tony Blair's Brexit speech (Rowson, The Guardian, 17 February 2017) https://www.theguardian.com/commentisfree/picture/2017/feb/17/martinrowson-tony-blair-brexit-speech-cartoon

The cartoon depicts Tony Blair caricatured as a one-legged skeleton raising the European flag in his right hand and carrying the bone of his right leg in his left hand. Behind him stands Boris Johnson pointing a gun aiming at his back, instead of pointing at the enemy. Jeremy Corbyn, lying on the ground, legs crossed, appears quite unperturbed by the scene. Again we find multimodal cueing, with the caption "A Liberty leading the people", providing access to the July Revolution of 1830 scenario, and the visual representation and the perceptual resemblance to the scene depicted in Delacroix's painting also cues the Revolution scenario. The main incongruities are the figurative representation of Tony Blair as a skeleton in the role of La Marianne, leading the fight for 'Remain', cued by the European flag, but carrying the bones of his right leg instead of a 
musket in his left hand and followed by monsters (resembling Norse trolls). The representation conjures up the image of a necromancer, so-called "bone-conjurers", with huge jaws and teeth as part of a horned skull, which appears to be a necromancer's Helmet. The fact that Boris Johnson is taking a pot shot at Blair, rather than at the enemy is also incongruous with respect to the 1830 Revolution scenario. At the same time, the verbal caption introduces a variation in the title of the painting, it is no longer "Liberty leading the people", but "A Liberty", a clear allusion to the phrase 'take a liberty with"

The apparent paradox in the visual fusion of the skeleton with the goddess of Liberty leading the revolt in defence of the democratic ideals of the EU serves to portray Tony Blair as a political cadaver, and having dealings with dark forces; Blair is trying to take the lead for Bremain without permission, in spite of being de-legitimized as a leader. In line with this, there is a comment by one reader, AwkyOrko (17 Feb 2017 21:04), who very aptly sums it up: “'Hasn't a leg to stand on'-brilliant”. The cartoon posits a general critique of the dominant political elite in the UK, and especially the left. Jeremy Corbyn and the Labour party have proved to be totally ineffective in the Bremain campaign. And Blair's call for a cross-party political movement against Brexit is obviously opposed by Boris Johnson. The critical stance of the cartoonist suggests that the UK is in the hands of political cadavers, ineffectual leaders and treacherous zealots.

\subsection{ALLEGORY, MYTH \& SYMBOL IN REPRESENTATIONS}

The cartoons draw on a variety of symbolic images, allegorical representations, historical figures as source domain characters, in the representation of the main social actors of Brexit, who are recurrently caricatured as BRITANNIA, JOHN BULL, or as personanimal hybrids, THE BRITISH LION, and THE BRITISH BULLDOG. Some of the common visual metaphors instantiated are: MAY IS BRITANNIA, JOHNSON IS THE BRITISH LION, MICHAEL GOVE IS THE BRITISH BULLDOG, MAY IS ELIZABETH I.

The cartoon by Chris Riddell draws on two separate items of news for its contextualization: "US president, visiting London, says "part of being friends is being honest' as he lays out perils of leave vote in EU referendum" ("Barack Obama: Brexit would put UK 'back of the queue' for trade talks", Guardian, 22 April 2016), and the news of Prince's sudden death on 21 April 2016.

(3) Brexit campaigners take their lead from Prince (Riddell, The Guardian, 24 April 2016)

https://www.theguardian.com/commentisfree/picture/2016/apr/24/brexitcampaigners-take-their-lead-from-prince

The cartoon depicts Theresa May as the Goddess Britannia ${ }^{5}$, on her shield the Union Jack with the words BREXIT, escorted on a downward path towards darkness by John Bull ${ }^{6}$, an allegorical figure and the personification of England, wearing a waistcoat also with the Union Jack flag. They are followed by Boris Johnson, caricatured as the

\footnotetext{
4 "If you take liberties or take a liberty with someone or something, you act in a way that is too free and does not show enough respect" (Collins COBUILD).

5 "The Romans created a goddess of Britannia, wearing a Centurion helmet and toga, with her right breast exposed. In the Victorian period, when the British Empire was rapidly expanding, this was altered to include her brandishing a trident and a shield with the British flag on, a perfect patriotic representation of the nation's militarism". (Ben Jonson: Rule Britannia, https://www.historic-uk.com/)

6 "During the Napoleonic Wars, John Bull became the national symbol of freedom, of loyalty to king and country, and of resistance to French aggression. He was the ordinary man in the street, who would fight Napoleon with his bare hands if necessary". (Ben Jonson: John Bull, https://www.historic-uk.com/)
} 
Barbary lion, the national animal of England, leading a dog by the leash. The dog is a caricature of Michael Gove as the British bulldog, popularly representing the UK. The salient scenario and the resemblance of the caricature of John Bull to that of the Prince Regent appear to evoke the extravagant and hedonistic lifestyle of the Regency period of George IV (1762-1830) ${ }^{7}$. However, the verbal cues in the cartoon prompt access to an alternative scenario; the caption and the speech bubble, both allude to the singer Prince: "Brexit campaigners take their lead from Prince", and "We are going to party like it's 1899". The lyrics in the song '1999' by American musician Prince include the following: "Tryin' to run from the destruction, you know I didn't even care ... Say say two thousand zero zero party over, oops, out of time... So tonight I'm gonna party like it's nineteen ninety-nine". The political message is transparent: the Conservatives are behaving in an irresponsible manner, following the motto 'Live like today's your last', and are blind to the dangers of Brexit. The critique of May's position, and that of Conservative leaders in favour of leaving EU, is shared in the following Guardian comment by Caldy1 (24 Apr 2016): "The blinkered, with the deluded and disingenuous".

\subsection{RECONTEXTUALIZATION AND INTERTEXTUALITY}

In the cartoons we find various forms of allusions to historical events together with recontextualisation of quotes, proverbs or sayings, from literary or historical sources, songs, and so on. In the collection of cartoons compiled, there are a number of captions with various form of recontextualization, such as Chris Riddell on "the true aims of the former London mayor's Brexit campaign", in the Observer comment cartoon with the title "Ambition, thy name is Boris Johnson", which ironically alludes to Hamlet's "Frailty, thy name is woman" (The Guardian/The Observer, Riddell 05/06/2016). Similarly, Steve Bell, in the cartoon "on the UK's EU divorce bill”, depicts Boris Johnson caricatured as John Bull saying 'Go whistle', which refers to his speech in Parliament where he suggested that "European leaders can 'go whistle' if they expect Britain to pay a divorce bill for withdrawing from the European Union" (The Guardian, 11/07/2017), and which is also a recontextualization of the quote "Let the law go whistle" from The Winter's Tale (The Guardian, Bell 11/07/2017). From the poem "The Walrus and the Carpenter" in Alice in Wonderland, we find an allusion to the quote "and whether pigs have wings", and to the phrase 'If pigs could fly', in Chris Riddell's comment cartoon on "Tory Brexit teeters on the brink - cartoon. Weighed down by economic forecasts and the Irish border question, what are the chances of this pig flying?" (The Guardian/The Observer, Riddell 27/05/2018). In the cartoon by Chris Riddell "Britain goes to hell in a Brexit handcart" (The Guardian, Riddle 18/08/2018), the caption 'No Brexit is better than a bad Brexit' is a recontextualization and reversal of the intended meaning of the quote "No eye at all is better than an evil eye", from Dicken's A Christmas Carol, alluding to the issue of dangerous falsehoods and the fallacy that a no-deal Brexit cannot harm the UK.

From historical sources we examples of recontextualizations such as the quote usually attributed to King Louis XV of France (1710-74), "Après moi, le déluge" ("After me, the flood'), after the defeat of the French and Austrian armies by Frederick the Great at Rossbach in 1757, which is found in the cartoon by Steve Bell "on George Osborne and his warnings over Brexit" (The Guardian, Bell 23/05/2016), in reference to George

\footnotetext{
${ }^{7}$ The Prince of Wales was "extravagant and entertained lavishly, moving in a set of people who shared in his excesses of gambling and drinking".

(Rachel Knowles: https://www.regencyhistory.net/2011/10/george-iv.html).
} 
Osborne's warning that "Britain would face a year-long 'DIY recession' following a vote to leave the European Union" (The Guardian, 23/05/2016).

The following cartoon provides a further example of recontextualization, which we will comment in more detail. The contextualization for this cartoon can be found in the news about the attitude of EU diplomats to Theresa May's Chequers White paper: "EU diplomats remain guarded over May's Brexit compromise. Diplomats uneasy about giving UK unique status outside EU" (The Observer, 7 July 2018). In the article, mention is made of a diplomatic source describing May's plan as "a lot of fudge with a cherry on top". Reference is also made to May's proposal regarding the customs compromise, which is similar to the previous proposal "to create an invisible border in Ireland after Brexit", which had been turned down by the EU, who accused the UK of "magical thinking" (The Guardian, 25/08/2017).

(4) After Chequers, soft Brexit is coming home - cartoon. Chris Riddell on the 'rough creature slouching towards Brussels to be born': Fudge, the Brexit unicorn. (Riddell, The Guardian, 7 July 2018) https://www.theguardian.com/commentisfree/picture/2018/jul/07/afterchequers-soft-brexit-is-coming-home-cartoon

As regards content, the cartoon shows a half-starved unicorn, the Brexit unicorn, running frantically, foaming at the mouth, and carrying a signboard with the words: 'Fudge', the Brexit unicorn, in reference to May's Chequers deal for Brexit. There are multiple verbal cues: the speech bubble with the words "It's coming home, it's coming home, soft Brexit is coming home", and the captions "And what rough creature, its hour come at last, slouches towards Brussels to be born?" and "With apologies to W. B. Yeats". The speech bubble alludes to the de facto 'anthem' of English football since 1996, when England hosted the European championships, with the refrain "It's coming home", from the song "Three Lions", also "Three Lions (Football's Coming Home)" by The Lightning Seeds.

The captions, however, prompt access to a far less jovial scenario; they allude to the quote "And what rough beast, its hour come round at last, Slouches towards Bethlehem to be born?", from The Second Coming, a poem by Irish poet W. B. Yeats in 1919. The poem alludes to St. John's biblical Revelation of the Apocalypse and the second coming of Christ, to allegorically refer to the atmosphere of post-war Europe and to the vision of the apocalyptic future of Ireland. The political message of the cartoon highlights, on the one hand, the unrealistic proposals made by May and that reality will win over Brexit fantasy, and on the other, evokes the precarious situation of the UK and the Irish border, and the potential catastrophic effects of leaving the EU.

\subsection{RECONTEXTUALISATION AND NARRATIVE GENRES}

The Brexit cartoons repeatedly draw on narrative genres as framing and reframing devices in the representation of politicians and political events. We find visual representations evoking characters and events in well-known fairy tales, works of literary fantasy, films, legends and so on, such as: Red Riding Hood, Cinderella, Pied Piper of Hamelin, Snow White; Alice in Wonderland; Game of Thrones, Star Wars, Mad Max, Living Dead, Scream, Friday 13, Elm Street, to name a few. As in these literary forms, we also find (wild) animals, mythical creatures and supernatural adversaries, such as wolves, bears, pigs, elephants, unicorns, trolls, Devil, White Walker in the role of characters in the cartoons, in the visual representation and caricatures of politicians. These 
visual representations instantiate metaphors such as: MAY IS RED RIDING HOOD, BREXIT IS UNICORN, BREXIT IS THE DEVIL, BREXIT IS GHOST FACE, MAY IS WHITE WALKER, DUP IS FREDDY KRUEGER.

The following cartoon by Chris Riddel draws on the fairy tale Red Riding Hood. but recontextualizes it with a sinister twist. The cartoon portrays the scene where little Red Riding Hood is walking out of the woods with her Brexit basket with food for her sickly granny. May, depicted as the young girl, is smiling confidently and saying "We're out of the woods!", meaning 'out of danger'. She appears to be completely unaware that she is surrounded by the Big Bad Wolf, representing the 'falling pound', a Big Grizzly Bear, representing the 'public finances', and an Orc, a humanoid creature representing 'inflation'.

(5) Brexit: a sinister fairytale. (The Guardian, Riddell, 30 December 2016) https://www.theguardian.com/commentisfree/picture/2016/oct/30/brexit-asinister-fairytale

Through this cartoon, Chris Riddell expresses his critical commentary on the false optimism of the Brexiters, and refers to the dangers of Brexit and the potential catastrophic economic effects thereof.

The following cartoon, also by Chris Riddell, draws on the television series Game of Thrones, based on the series of fantasy novels by George R. R. Martin, A Song of Ice and Fire, which chronicles the web of dynastic alliances and conflicts among a number of noble families plotting to attain the Iron throne, as well as the fight for independence of other noble families. The story provides the perfect setting for an allegorical representation and critique of the political intrigue of Tories and Labour in the process of Brexit.

(6) May's game of thrones - cartoon. (The Guardian, Riddell, 3 Sept. 2017) https:/www.theguardian.com/commentisfree/picture/2017/sep/03/maysgame-of-thrones-cartoon

In the cartoon, Chris Riddell provides a critical commentary to the Prime Minister's pledge to stand in the next general election. He depicts May as a White Walker, a humanoid creature who represents a supernatural threat to mankind, a subgrouping of an undead race whose dismembered parts may still remain animated. In the cartoon Theresa May is saying, "I lied about the snap election, I lied about Brexit not being a disaster but believe me, I am going to go on and on and on ...", which expresses a paradoxical pledge, which sounds more like a threat. On the snow, there is a letter from Michel Barnier, the European Chief Negotiator for the United Kingdom Exiting the European Union, which warns May that "Winter is coming", in allusion to the end of the tether of European patience.

\section{CONCLUSION}

This paper has explored the potential of political cartoon discourse for creativity, critique and persuasion, and has presented a case study on the representation of main social actors and events involving Brexit in cartoons from the quality newspapers The Guardian and The Observer, both having a pro-Remain stance. As has been observed in the literature (Fauconnier and Turner, 2002; Bergen, 2004), common metaphors are found in the language of politicians and the media, and in the cartoons. Some recurring source 
domains are the following: JOURNEY/PATH, NATURAL DISASTER, GAME OF DRAUGHTS (OR CHECKERS), FIGHTING/WAR, and so on.

The paper has argued that political cartoons provide the ideal site for metaphorical creativity as novelty and as recontextualization, which often take the form of unexpected twists in familiar scenarios, and incongruity in the form of novel and discordant elements in the cartoon. The main features of innovation and recontextualisation have been found in the use of symbolic images, allegorical representations, caricatures based on famous historical figures, mythological creatures, person-animal hybrids, wild animals, monsters and supernatural adversaries, and so on. Recontextualization and intertextuality have been found in the use of ironic allusions and quotations from historical and literary sources, or parody. Both are similarly present in the use of various narrative genres as framing and re-framing devices, as in familiar fairy tales, legend, films, songs, and so on.

The role of political cartoons as instruments of critique has also been discussed; cartoons challenge political power and provide a site of contest for symbolic power, and for dissent and transgression. This paper has shown how the Brexit negotiations are represented as unrealistic proposals, which are fudging the crucial issues and mystifying falsehoods. The representations of social actors depict UK politicians as arrogant, ambitious, ineffectual, irresponsible, and as treacherous zealots in some cases. The cartoons function as vehicles of persuasion by drawing on features of figurative framing and the power of counter-narratives and counter-scenarios. Some common instances of counter-narratives draw on well-known fairy tales or legends, but underscoring the presence of danger, destruction and the path to Hell. The cartoons similarly play a crucial role in the de-construction of pro-Brexit scenarios by providing figurative counterscenarios as plausible frames for evaluating the consequences of Brexit involving irreality or fantasy.

\section{REFERENCES}

Bergen, Benjamin. 2004. "To awaken a sleeping giant. Cognition and culture in September 11 political cartoons". In Language, Culture and Mind, eds. Michel Achard and Suzanne Kemmer. Stanford, CA: CSLI, pp. 23-36.

Bourdieu, Pierre. 1991. Language and Symbolic Power. Cambridge: Polity Press.

Brône, Geert and Kurt Feyaerts. 2003. The cognitive linguistics of incongruity resolution: Marked reference-point structures in humor. Conference Proceedings Preprint 205. University of Leuven, Department of Linguistics. Leuven: Katholieke Universiteit Leuven, pp. 1-58.

Charteris-Black, Jonathan. 2011. Politicians and Rhetoric. The persuasive power of metaphor. London \& New York: Palgrave MacMillan.

Chilton, Paul and Mikhail Ilyin. 1993. "Metaphor in Political Discourse: The Case of the 'Common European House'”. Discourse \& Society, 4 (7): 7-31.

Coulson, Seana. 2002. "What's so funny? Conceptual integration in humorous examples". [http://cogsci.ucsd.edu/ coulson/funstuff/funny.html].

Douglas, Mary. 1968. "The social control of cognition: Some factors in joke perception". Man 3 (3): 361-376.

Fauconnier, Gilles and Mark Turner. 2002. The Way We Think. New York: Perseus Books.

Forceville, Charles. 2009. "Non-verbal and multimodal metaphor in a cognitivist framework: Agendas for research". In Multimodal Metaphor, eds. Charles Forceville and Eduardo Urios-Aparisi. Berlin/New York: Mouton de Gruyter, pp. $19-42$. 
Gibbs, Raymond W. 2015. "The allegorical character of political metaphors in discourse". Metaphor and the Social World 5(2): 264-282.

Giora, Rachel (2003). On Our Mind: Salience, Context and Figurative Language. New York: Oxford University Press.

Hidalgo Downing, Laura, Kraljevic Mujic, Blanca and Begoña Núñez-Perucha. 2013. "Metaphorical creativity and recontextualization in multimodal advertisements on e-business across time". Metaphor and the Social World, 3 (2): 199-219.

Holland, Dorothy and Naomi Quinn. 1987. Cultural Models in Language and Thought. Cambridge: Cambridge University Press.

Johnson, Paul and Ian Mitchell. 2017. "The Brexit vote, economics, and economic policy". Oxford Review of Economic Policy, 33 (S1): S12-S21.

Kaufman, James C. and Robert J. Sternberg. 2010. "Constraints on Creativity. Obvious and Not So Obvious". In The Cambridge Handbook of Creativity, eds. James C. Kaufman and Robert J. Sternberg. Cambridge: Cambridge University Press, pp. 467-482.

Koestler, Arthur. [1964] 1989. The Act of Creation. [London: Hutchinson] London: Arkana, Penguin Books.

Kövecses, Zoltán. 2010. "A new look at metaphorical creativity in cognitive linguistics". Cognitive Linguistics, 21: 663-697.

Lakoff, George and Mark Johnson. 1999. Philosophy in the Flesh: The Embodied Mind and its Challenge to Western Thought. New York, NY: Basic Books.

Langlotz, Andreas. 2015. "Language, creativity, and cognition". In The Routledge Handbook of Language and Creativity, ed. Rodney H. Jones. London: Routledge, pp. 40-60.

Machin, David. 2013. "What is multimodal critical discourse studies?". Critical Discourse Studies, 10 (4): 347-355.

Marín-Arrese, Juana I. 2005. "Humour as Subversion in Political Cartooning". In Approaches to Critical Discourse Analysis, ed. M. Labarta Postigo. Valencia: Universitat de València, Servei de Publicacions. CD, pp. 1-22.

—. 2008. "Cognition and culture in political cartoons". Intercultural Pragmatics, 5 (1): $1-18$.

-. 2015. "Political Cartoon Discourse". In The International Encyclopedia of Language and Social Interaction, eds. Karen Tracy (General Editor), Cornelia Ilie and Todd Sandel (Associate Editors). Boston: John Wiley \& Sons, Inc.

—. in press. "Metaphorical creativity in Political Cartoons: The Migrant Crisis in Europe". In Performing metaphorical creativity in context: exploring modes and cultures, eds. Laura Hidalgo-Downing and Blanca Kraljevic-Mujic. (Figurative Thought and Language Series). Amsterdam: John Benjamins.

Mayhew, Ken. 2017. "UK higher education and Brexit". Oxford Review of Economic Policy, 33 (suppl_1): S155-S161.

Musolff, Andreas. 2006. "Metaphor Scenarios in Public Discourse". Metaphor and Symbol, 21(1): 23-38.

-. 2012. "The study of metaphor as part of critical discourse analysis". Critical Discourse Studies, 9 (3): 301-310.

—. 2017. "Truths, lies and figurative language". Journal of Language and Politics, 16 (5): 641-657.

Reijnierse, W. Gudrun, Burgers, Christian, Krennmayr, Tina and Gerard J. Steen. 2015. "How viruses and beasts affect our opinions (or not). The role of extendedness in metaphorical framing". Metaphor and the Social World 5(2): 245-263. 
Schilperoord, Joost and Alfons Maes. 2009. "Visual metaphoric conceptualization in editorial cartoons". In Multimodal Metaphor, eds. Charles Forceville and Eduardo Urios-Aparisi. Berlin/New York: Mouton de Gruyter, pp. 213-240.

Semino, Elena, Deignan, Alice, and Jeannette Littlemore. 2013. "Metaphor, genre and recontextualization". Metaphor and Symbol 28 (1): 41-59.

Speier, Hans. 1998. "Wit and politics: An essay on laughter and power". American Journal of Sociology 103 (5): 1352-1401.

Sternberg Robert J. and T.I. Lubart. 1999. "The concept of creativity: prospects and paradigms". In Handbook of Creativity, ed. Robert J. Sternberg. Cambridge: Cambridge University Press, pp. 3-15.

Thurlow, Crispin and Adam Jaworski. 2017. "Introducing elite discourse: the rhetorics of status, privilege, and power". Social Semiotics, 27 (3): 243-254,

Van Dijk, Teun. 1998. Ideology: A Multidisciplinary Approach. London: Sage Publications.

Wodak, Ruth and Michael Meyer. 2015. "Critical Discourse Studies: History, agenda, theory and methodology". In: Methods of Critical Discourse Studies, 3rd ed., eds. Ruth Wodak and Michael Meyer. London: Sage, pp. 1-22. 